\title{
An Innovative Approach to Achieve Engineering Graduate Outcomes
}

\author{
Srivatsa $\mathrm{Ch}^{1}$, Vijetha Ringu ${ }^{2}$ \\ ${ }^{1}$ Department of computer science and engineering, Nalla Malla Reddy Engineering College \\ ${ }^{2}$ Department of computer science and engineering, Nalla Malla Reddy Engineering College \\ ${ }^{1}$ srivatsa.cse@nmrec.edu.in \\ ${ }^{2}$ vijetha.cse@nmrec.edu.in
}

\begin{abstract}
In today's technology driven era, education becomes vital for developing the generation of innovators and artistic thinkers. The process of identifying problems and providing solutions constitutes research. It is very essential for engineering students to analyse and orient themselves to research thinking which could be very much useful for them in later stages. But the present engineering curriculum does not encourage research until final year. To bridge this gap, this paper proposes a new strategy to be implemented at the early stage of engineering. The idea is to help in orienting the students towards research which is an essential requirement in engineering education. This paper presents our idea - An Innovative Approach to Achieve Engineering Graduate Outcomes (IAAEGO).
\end{abstract}

Keywords: Graduate Outcomes, Course outcomes, Innovative assignment, Research oriented learning.

\section{INTRODUCTION}

Research plays a major role in graduate and post graduate courses as it enhances the attainment of graduate attributes [4]. Current curriculum does not completely support development of research thinking among engineering students. Though they have to do project in their final semester, till then they are expected to learn theory and practical on those theoretical subject but the curriculum does not provide facility to focus on research.

On the other hand, assignments in engineering courses hold a great importance. Assignments are given to evaluate students' understanding of the subject and to enhance their knowledge on the given topic[1],[2]. The reason behind giving assignments is to maximize the educational ability of students. Further, it is a great way to increase a student's practical skills. Assignments help in achieving more number of graduate attributes such as Engineering knowledge, Problem analysis, design and development of solutions, etc.

\author{
Vijetha Ringu \\ Department of Computer Science and Engineering \\ Nalla Malla Reddy Engineering College \\ Divyanagar, Hyderabad. \\ vijetha.cse@nmrec.edu.in
}

In current scenario most of the university curriculum focuses on theory courses and laboratories related to the theory course and projects at final semester of their engineering course. As most of the time students are learning only theory and working on practical related to those theory courses there is very less scope of working on research or knowing more about how to do research and the importance of research. In final semester they are expected to come up with problem statement and do some research work to come up with a solution to the stated problem. But at this point students are compelled to work in short period of time and with no earlier experience in research and also they are left with less time to do research work on their problem statement. This is leading them to fail in producing good quality projects involving research. Plagiarism is also rampant in final year projects due to their inability to understand research methodology.

This paper presents an innovative assignment which is used to improve student's technical knowledge as well as to map the course outcomes to other Graduate Attributes like Conducting Investigation of complex programs, Lifelong learning and Communication [3][4].

\section{Innovative Approach To Achieve Engineering Graduate Outcomes}

\section{A. OVERVIEW}

An innovative approach is proposed that achieves the required graduate attributes in engineering. Its main objective is to improve the significance of Research, strengthening of academics and communication skills. It also enhances the Understanding of the concept of the topic from different angles and reproducing the same according to the individual's capacity. It also helps in improving presentation skills and Breaks the copy and paste method which student usually does while writing assignments. 


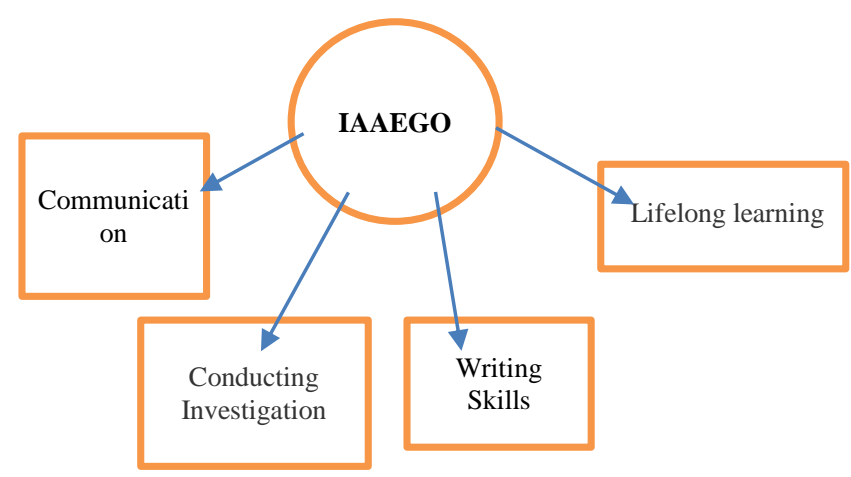

Fig 1: Benefits of the new Innovative Approach to Achieve Engineering Graduate Outcomes.

\section{B. METHODOLOGY}

This paper presents an innovative method to inculcate research thinking among students. This was implemented with second year undergraduate students of Computer Science and Engineering department for the course Mathematical Foundation for Computer Science.

In this method each student is given a topic from their curriculum. The students are supposed to collect a few published research papers on that topic. Then after studying the abstract of each paper, out of those collected papers they have to select one paper. If they are not able to choose the paper, they can take help of their faculty. Later, they have to study that selected paper thoroughly, summarise it and relate it to real time usage. Then they have to submit the summary to respective faculty and also student should give a seminar in the class. This proposed method also helps in assessment. As not all course outcomes can be assessed in internal exams, this helps in covering those topics which could not be covered in internal examinations.

\section{RUBRICS}

Rubrics are prepared for assigning marks based on the observations. Assessment will be done for 5 marks as these marks will be added for the internals, and interested students are encouraged for new projects. Proper guidance will be given for weak students.

Table 1. Rubrics for Innovative Approach To Achieve Engineering Graduate Outcomes

\begin{tabular}{|l|l|l|l|}
\hline Activity & 2 Marks & 1 Mark 0 Marks \\
\hline $\begin{array}{l}\text { Number of } \\
\text { papers }\end{array}$ & $\begin{array}{l}\text { Min of 5 } \\
\text { papers } \\
\text { Collected } \\
\text { on the } \\
\text { collected be } \\
\text { given topic }\end{array}$ & $\begin{array}{l}\text { Number of } \\
\text { papers } \\
\text { collected } \\
\text { between 3-5 }\end{array}$ & $\begin{array}{l}\text { Number of } \\
\text { papers } \\
\text { collected less } \\
\text { than 3. }\end{array}$ \\
\hline
\end{tabular}

\begin{tabular}{|c|c|c|c|}
\hline $\begin{array}{l}\text { Selected } \\
\text { paper }\end{array}$ & & $\begin{array}{l}\text { Is the } \\
\text { selected } \\
\text { paper } \\
\text { relevant to } \\
\text { the topic } \\
\text { given? }\end{array}$ & $\begin{array}{l}\text { Is the } \\
\text { selected } \\
\text { paper } \\
\text { irrelevant to } \\
\text { the topic } \\
\text { given? }\end{array}$ \\
\hline $\begin{array}{l}\text { Write up on } \\
\text { selected } \\
\text { paper }\end{array}$ & $\begin{array}{l}\text { Summary } \\
\text { with proper } \\
\text { explanation } \\
\text { with } \\
\text { technical } \\
\text { terms }\end{array}$ & $\begin{array}{l}\text { Summary } \\
\text { without } \\
\text { proper } \\
\text { explanation }\end{array}$ & No summary \\
\hline $\begin{array}{l}\text { Seminar - } \\
\text { After } \\
\text { submitting } \\
\text { the } \\
\text { summary, } \\
\text { the student } \\
\text { has to give } \\
\text { a small talk } \\
\text { on their } \\
\text { topic and } \\
\text { its usage in } \\
\text { real world }\end{array}$ & & $\begin{array}{l}\text { Highly } \\
\text { confident } \\
\text { about the } \\
\text { work they } \\
\text { have done }\end{array}$ & $\begin{array}{l}\text { Not fully } \\
\text { confident }\end{array}$ \\
\hline
\end{tabular}

\section{QUESTIONNAIRE}

A survey was conducted on IAAEGO by collecting student feedback. The students who participated in this course were given a questionnaire with 5 questions. The survey form was sent to all the students through Google classroom. Survey format consists of dichotomous, rating scale type of queries. The survey questionnaire contains the questions as in table 2 Table 2. Survey Questionnaire

\begin{tabular}{|c|c|}
\hline Q.No & Question \\
\hline Q1 & $\begin{array}{l}\text { As per assignment given to you how much did that } \\
\text { help you learning new things? Rate between } 5 \text { to }\end{array}$ \\
\hline Q2 & $\begin{array}{l}\text { As per assignment given to you, did it help you to } \\
\text { increase your writing skills? }\end{array}$ \\
\hline Q3 & $\begin{array}{l}\text { Did this new assignment pattern help you to learn } \\
\text { new things and explore further. }\end{array}$ \\
\hline Q4 & $\begin{array}{l}\text { To what extent did you learn to implement this } \\
\text { subject in Real Time. Scale from } 1 \text { to } 5,1 \text { being } \\
\text { Very Good and } 5 \text { being Ok. }\end{array}$ \\
\hline Q5 & $\begin{array}{l}\text { How much are you motivated to learn new things } \\
\text { with this new assignment. Scale from } 1 \text { to } 5,1 \\
\text { being Very Good and } 5 \text { being Ok. }\end{array}$ \\
\hline
\end{tabular}




\section{RESULTS AND OBSERVATIONS}

As per the survey, $88.9 \%$ of students accepted that their writing skills have improved, $70.4 \%$ of students accepted that it helped them to explore innovative approaches to Technology, $77.7 \%$ of students have agreed that it helped them to know how to implement the subject in Real Time, $81.4 \%$ of students are satisfied with this method of assignment. The survey results are shown below.

\section{FIGURES}

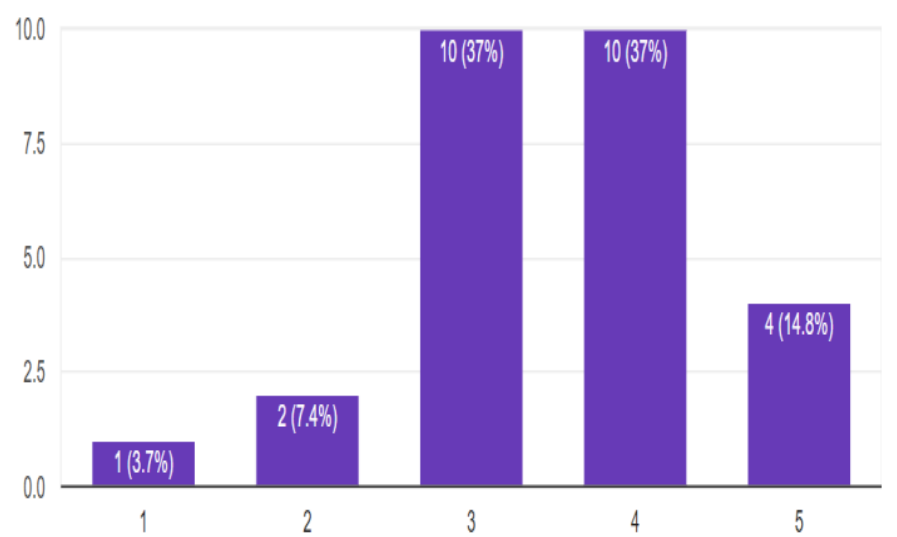

Fig 2: Bar Graph showing the result for Q1 in the survey.

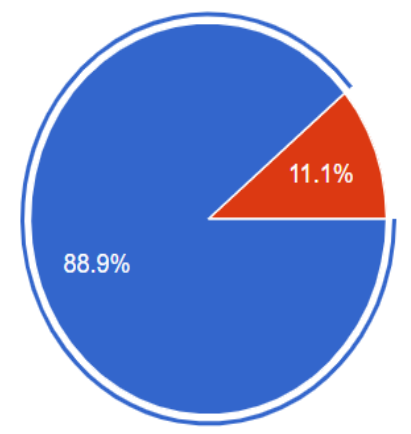

Fig 3: Pie Chart showing the result for $\mathbf{Q 2}$ in the survey.

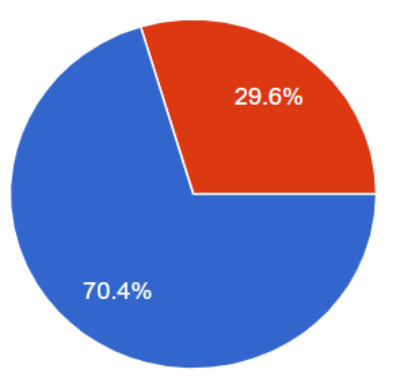

Fig 4: Pie Chart showing the result for Q3 in the survey.

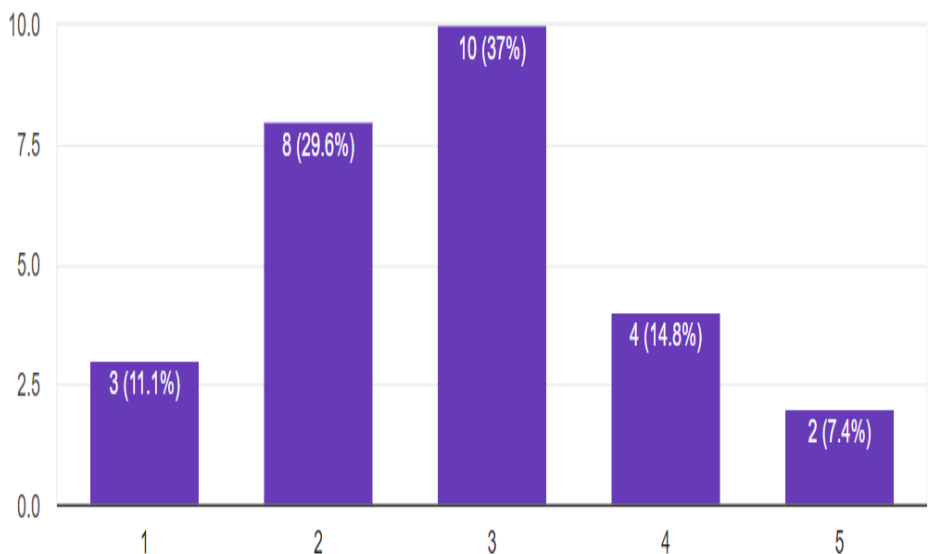

Fig 5: Bar Graph showing the result for Q4 in the survey

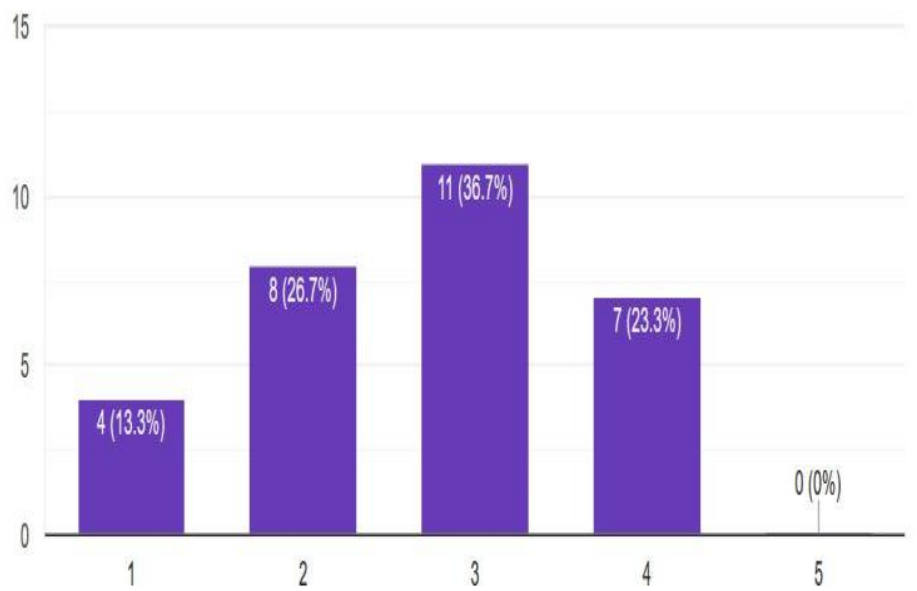

Fig 6: Bar Graph showing the result for Q5 in the survey

\section{Conclusion}


It was observed that by implementing this method out of 110 students, most of the students had shown their interest in exploring new technologies. It also motivated to explore the subject in Real Time through Research Papers. Thus resulting in enhancing their research skills, technical knowledge, writing skills and subject proficiency.

The idea can be further implemented in various ways like studying two or more papers and comparing them and coming up with a write up on what they have learned and what questions have been answered by the papers they have studied. The authors plan to implement these methods in their future courses.

\section{REFERENCES}

[1] Dr. Otilia Popescu, Dr. Vukica M. Jovanovic, Old Dominion University, "Introducing Writing Assignments in Engineering Technology Courses to Enhance Technical Writing Skills and Critical Thinking", presented in ASEE $123^{\text {rd }}$ annual conference \& Exposition held from 26$29^{\text {th }}$ June, 2016, at New Orleans, LA.

[2] Roger Graves, University of Alberta, and Anne Parker and Kathryn Marcynuk, University of Manitoba, "Undergraduate Writing Assignments in Engineering: Some Preliminary Findings", presented at Canadian Engineering Education Association (CEEA12) Conference Proceedings, held from 17- 20 ${ }^{\text {th }}$ June, 2012 at Manitoba, Canada.

[3] Uma Garimella, Divya Nalla, "Moving towards Outcome-based Education-Faculty development Initiatives", 2014, IEEE Frontiers in Education Conference(FIE) Proceedings, Madrid, 2014, pp. 1-8

[4] Dr. Divya nalla ,Dr. Sneha Nalla, "Research Culture in Engineering Faculty: Its effect on the attainment of Graduate attributes", presented in $46^{\text {th }}$ IEEE sponsored International Conference Frontiers in Education-FIE 2016, held from 12$15^{\text {th }}$ October 2016, at Erie, PA, USA 